\title{
Modulation of Epidermal Growth Factor Stimulated ERK Phosphorylation and Cell Motility by Inositol Trisphosphate Kinase
}

\author{
M. C. Sekar ${ }^{1,{ }^{*}}$, K. Shahiwala ${ }^{1}$, L. Leloup ${ }^{2}$, and A. Wells ${ }^{2}$ \\ ${ }^{1}$ College of Pharmacy, University of Findlay, Findlay, 45840, OH, USA \\ ${ }^{2}$ Department of Pathology, University of Pittsburgh, Pittsburgh, 15261, PA, USA
}

\begin{abstract}
Epidermal growth factor [EGF] mediated stimulation of its receptor in endothelial cell $[\mathrm{EC}]$ is accompanied by phosphorylation of the EGF-receptor [EGFR] and activation of phospholipase C$\gamma$, resulting in the breakdown of phosphatidylinositol(4,5)-bisphosphate and generating inositol $(1,4,5)$-trisphosphate $\left[\mathrm{IP}_{3}\right]$ and diacylglycerol. $\mathrm{IP}_{3}$ thus formed can be further converted to inositol $(1,3,4,5)$-tetrakisphosphate $\left[\mathrm{IP}_{4}\right]$ by an enzyme called $\mathrm{IP}_{3}$-kinase $\left[\mathrm{IP}_{3} \mathrm{~K}\right]$. In this study we have investigated the effect of modulation of intracellular $\mathrm{IP}_{3} \mathrm{~K}$ activity by the use of an inhibitor, 2trifluoromethyl [6-(4-nitrobenzyl)-purine] [ $\left[\mathrm{IP}_{3} \mathrm{KI}\right]$ and siRNA against $\mathrm{IP}_{3} \mathrm{~KB}$ on EGF-induced ERK-phosphorylation and cell motility. EGF stimulated ERK-phosphorylation that has been implicated in EGF-stimulated cell migration was inhibited by both $\mathrm{IP}_{3} \mathrm{KI}$ and siRNA against $\mathrm{IP}_{3} \mathrm{~KB}$. Inhibition of ERK-phosphorylation was accompanied by decreased cell migration in the presence of $\mathrm{IP}_{3} \mathrm{KI}$.
\end{abstract}

\section{Keywords}

Inositol Phosphates; EGF Receptor; Cell Migration

\section{INTRODUCTION}

Epidermal growth factor receptor activated PLC- $\gamma$ mediated pathway increases cell motility by inducing the cytoskeletal reorganization that is required for asymmetric cell locomotion (Chen et al., 1996). Phospholipase C- $\gamma$ activation cleaves phosphoinositide 4,5-bisphosphate $\left(\mathrm{PIP}_{2}\right)$ into inositol 1,4,5-trisphosphate ( $\left.\mathrm{IP}_{3}\right)$ and diacylglycerol (Berridge, 1993). Inhibition of $\mathrm{PIP}_{2}$ breakdown results in failure of lamellipodium extension and cell motility (Chen et al., 1994). The importance of PIP $_{2}$ in cell motility was recently demonstrated by finding that detachment of rear of the cell necessary for cell motility requires $m$-calpain activation, which is localized at the rear of the cell in a PIP 2 enriched domain (Shao et al., 2006). EGFstimulated $m$-calpain activation is mediated through ERK1/2 phosphorylation (Galding et al., 2000) and inhibition of ERK1/2 phosphorylation is accompanied by decreased motility (Galding et al., 2001).

\footnotetext{
*Author to whom correspondence should be addressed. sekar@ findlay.edu.
} 
The open question remains of the function of PLC $\gamma$. Is it merely to remove $\mathrm{PIP}_{2}$ from the membrane mobilizing actin binding proteins and eliminating docking sites, or does it involve downstream signaling molecules? While the role of $\mathrm{IP}_{3}$ in calcium mobilization is well established (Berridge, 1993), role of other inositol phosphates, besides $\mathrm{IP}_{3}$, in various aspects of cell signaling are only now being recognized (Miller et al., 2008). Calcium contributes to transcellular contractility (Helfman et al., 1999) needed for motility (Lauffenburger et al., 1996). As $\mathrm{IP}_{3}$ generated in the cell is further converted to $\mathrm{I}(1,3,4$, 5) $\mathrm{P}_{4}$ by $\mathrm{IP}_{3}$-kinase (Irvine et al., 2006), we have investigated its function in this publication.

Currently, three isoforms of $\mathrm{IP}_{3}$-kinase, types- $\mathrm{A}, \mathrm{B}$ and $\mathrm{C}$ are shown to be present in

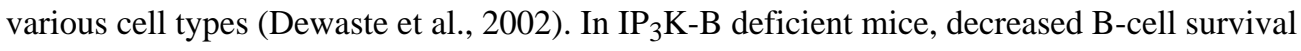
is associated with decreased phosphorylation of ERK1/2 (Marechal et al., 2007) and in a more recent study, overexpression of $\mathrm{IP}_{3} \mathrm{~K}$ type $\mathrm{A}$ has been associated with altered cytoskeletal reorganization and increased cell motility (Windhorst et al., 2008). In this study, we have investigated the effect of modulation of $\mathrm{IP}_{3} \mathrm{~K}$ activity with an $\mathrm{IP}_{3}$-kinase specific inhibitor $\left[\mathrm{IP}_{3} \mathrm{KI}\right]$ and a siRNA to $\mathrm{IP}_{3} \mathrm{~K}-\mathrm{B}$ on EGF-stimulated ERK-phosphorylation and cell motility.

\section{MATERIALS AND METHODS}

\section{Cell Culture}

Human microvascular endothelial cells (HMvEC) were grown in MCDB131, media supplemented with $10 \% \mathrm{FBS}, 1 \mu \mathrm{g} / \mathrm{mL}$ of hydrocortisone and $10 \mathrm{ng} / \mathrm{mL}$ of EGF.

\section{Study of ERK1/2 and EGFR Phosphorylations}

Cells were quiesced by overnight incubation with $0.1 \%$ dialyzed serum for endothelial cells (without EGF). Quiescent cells were washed once and incubated with or without $\mathrm{IP}_{3} \mathrm{KI}$ for 4 hrs and then stimulated with EGF (10 nM) for 0 to 20 minutes, as specified in the legend. Incubation terminated with hot lysis buffer. Proteins were separated by gel electrophoresis, transferred to PVDF membrane and probed with primary polyclonal antibodies against actin (Sigma-Aldrich), phosphorylated ERK1/2 (Cell Signaling Technology), and EGFR phosphorylated on Y1173 (Santa Cruz Biotechnology Inc.) and Y1068 (Cell Signaling Technology). The GAPDH (Monoclonal antibody obtained from rabbit) and secondary antibodies were purchased from Sigma-Aldrich.

\section{SiRNA Transfection and $\mathrm{IP}_{3} \mathrm{~K}$ Downregulation}

Endothelial cells were seeded at $80 \%$ confluency. The day after, the medium was removed and replaced by OptiMEM. The cells were then transfected with control siRNA or with 50 pmol of siRNA designed to knock-down $\mathrm{IP}_{3} \mathrm{~KB}$ (Santa Cruz Biotechnology) using Lipofectamine 2000 (Invitrogen). After 6 hours, the OptiMEM medium containing the siRNA and the Lipofectamine was removed and the cells were incubated overnight in regular medium (MCDB131). The down regulation of the $\mathrm{IP}_{3} \mathrm{~KB}$ expression was confirmed by immunoblot (antibody against $\mathrm{IP}_{3} \mathrm{~KB}$ obtained from Santa Cruz Biotechnology Inc.). The effects of this downregulation on the phosphorylation of ERK1/2 and EGFR were tested as described previously. 


\section{Wound Healing Assays}

Cell migration studies were done as described by us previously (Chen et al., 1996). Briefly, endothelial cells were grown up to confluency. After an overnight incubation in the quiescent medium, an acellular area (wound) was created by scraping the cells with a pipette tip. The cells were then washed and treated overnight with EGF $(10 \mathrm{nM})$ and increasing concentrations of $\mathrm{IP}_{3} \mathrm{KI}$ (Calbiochem, 0 to $20 \mu \mathrm{M}$ ). Pictures of the wound were taken before and after the overnight incubation. The closure of the wound was estimated using Metamorph software.

\section{RESULTS}

We queried whether $\mathrm{IP}_{4}$ may contribute to EGF-induced motility by determining the effect of $\mathrm{IP}_{3} \mathrm{~K}$ inhibitor $\left(\mathrm{IP}_{3} \mathrm{KI}\right)$ on cell migration by in vitro wound healing assay (Fig. 1). $\mathrm{IP}_{3} \mathrm{KI}$ alone, at $10 \mu \mathrm{M}$ and $20 \mu \mathrm{M}$, has no effect on basal cell motility, but it is clearly able to inhibit EGF-stimulated cell migration at the above concentrations.

As EGF-induced motility was blocked, we checked for EGFR signaling. Short-term activation of EGFR stimulation by EGF is accompanied by ERK phosphorylation. This EGF-stimulated ERK-phosphorylation is inhibited by pre-incubation with $20 \mu \mathrm{M}$ of $\mathrm{IP}_{3} \mathrm{KI}$ (Fig. 2(A)). Dose-dependent nature of this inhibition, with an $\mathrm{IC}_{50}$ between 10-15 micromolar, is further demonstrated in Figure 2(B). This value is comparable to that reported by Chang et al., 2002 in their in-vitro experiments on the ability of this compound to inhibit $\mathrm{IP}_{3} \mathrm{~K}$.

As this $\mathrm{IP}_{3} \mathrm{KI}$ inhibitor was obtained by screening an ATP inhibitor library, there was a possibility that both the above effects of this inhibitor (inhibition of EGF-stimulated ERKphosphorylation and motility) were due to the inhibition of the EGF-receptor kinase activity rather than $\mathrm{IP}_{3}$-kinase activity. This possibility was further investigated by studying the effect of $\mathrm{IP}_{3} \mathrm{KI}$ on EGFR phosphorylation (Fig. 3).

$\mathrm{IP}_{3} \mathrm{KI}$, not only inhibited EGF-stimulated ERK-phosphorylation as depicted in Figure 1, but it also clearly inhibited EGFR-phosphorylation at the same concentrations (Fig. 3(A)). Inhibitor decreased EGF-stimulated phosphorylation at both Y-1173 and Y-1068 (Fig. 3(B)). Though the extent of phosphorylation at these sites varied from experiment to experiment. This clearly raised the possibility that some or all of the effects of $\mathrm{IP}_{3} \mathrm{KI}$ could be explained by its direct inhibition of EGFR-kinase, rather than its inhibition of $\mathrm{IP}_{3} \mathrm{~K}$.

As a second, independent approach to eliminating $\mathrm{IP}_{4}$, and demonstrate that $\mathrm{IP}_{3} \mathrm{~K}$ is a key signaling molecule contributing to EGF-induced motility, we downregulated the main $\mathrm{IP}_{3} \mathrm{~K}$ isoform in endothelial cells, $\mathrm{IP}_{3} \mathrm{~KB}$, with $\mathrm{IP}_{3} \mathrm{~KB}$-specific siRNA (Fig. 4(A)). siRNA to $\mathrm{IP}_{3} \mathrm{~KB}$ decreased the expression of $\mathrm{IP}_{3} \mathrm{~KB}$ (Figs. 4(A) comparing lane 1 with 2 and 3 and lane 4 with 5 and 6). Comparing the EGF-stimulated $p$-ERK bands without and with $50 \mathrm{nM}$ siRNA concentrations clearly shows inhibition of phosphorylation with decreased $\mathrm{IP}_{3} \mathrm{~KB}$ expression (comparing lanes 1, 2, 3 with 4, 5, 6). 


\section{DISCUSSION}

$\mathrm{IP}_{3} \mathrm{KI}$ used in this study, 2-trifluoromethyl (6-(4-nitrobenzyl)-purine, was first reported by Chang et al., (2002). It was derived from screening the library of purine compounds and was suggested to compete for ATP binding site in $\mathrm{IP}_{3} \mathrm{~K}$ and thereby prevent phosphorylation of $\mathrm{IP}_{3}$ to $\mathrm{IP}_{4}$. Chang et al., (2002) reported that addition of this $\mathrm{IP}_{3} \mathrm{KI}$ to HeLa cells increased cytosolic calcium concentration over 1-2 min in a dose dependent manner. That was consistent with the inhibition of conversion of $\mathrm{IP}_{3}$ to $\mathrm{IP}_{4}$, which was accompanied by increased $\mathrm{IP}_{3}$-mediated cytosolic calcium increase. It is also possible that $\mathrm{IP}_{4}$ or downstream metabolite could play a role in inhibition of calcium release [Bird et al., 1996]. In that case $\mathrm{IP}_{3} \mathrm{KI}$ by preventing the formation of $\mathrm{IP}_{4}$ will remove that inhibition and enhance the release of calcium.

Rate limiting step for growth factor-induced chemokinetic movement is rear detachment, brought about by the activation of $m$-calpain [Galding et al., 2000, Galding et al., 2001]. $\mathrm{m}$ Calpain activation is achieved via ERK/mitogen-activated protein kinase, via the divergent Ras-Raf-MEK pathway to mediate focal adhesion disassembly. Inhibition of either the PLC$\gamma$ or ERK pathway leads to a loss of EGFR-mediated motility [Chen et al., 1996; Shao et al., 2006]. As $\mathrm{IP}_{3} \mathrm{KI}$ was shown to inhibit EGF-stimulated ERK phosphorylation in a dose dependent manner, we investigated the effect of this inhibitor on EGF-stimulated cell migration. As shown in Figure 2, $\mathrm{IP}_{3} \mathrm{KI}$ alone at 10 and $20 \mu \mathrm{M}$ concentration has no effect on endothelial cell migration while it clearly inhibits EGF-stimulated cell migration at both 10 and $20 \mu \mathrm{M}$ concentrations.

Interestingly, Windhorst et al., (2008) have reported that $\mathrm{IP}_{3}$-kinase type A overexpression in H1299 cells resulted in cytoskeletal reorganization as well as increased cell motility. Cell motility but not cytoskeletal reorganization was attributed to the enzymatic activity of $\mathrm{IP}_{3^{-}}$ kinase [Windhorst et al., 2008]. More recently increased expression of $\mathrm{IP}_{3} \mathrm{KA}$ increases invasive migration in vitro and metastasis in a xenograft SCID mouse model [Windhorst et al., 2010]. If enhanced activity of $\mathrm{IP}_{3} \mathrm{~K}$, as a result of $\mathrm{IP}_{3} \mathrm{~K}$ overexpression results in increased cell motility then our results that inhibition of $\mathrm{IP}_{3} \mathrm{~K}$ with $\mathrm{IP}_{3} \mathrm{KI}$ and downregulation of $\mathrm{IP}_{3} \mathrm{~KB}$ in our siRNA studies-leads to decreased ERK-phosphorylation accompanied by decreased cell motility would suggest the involvement of higher inositol phosphates in cell migration.

Eva et al., (2012) have recently reported that $\mathrm{IP}_{3}$-kinase type A activity opposes NGF stimulated neurite outgrowth that is accompanied by attenuation of ERK phosphorylation. Considering all the above studies on different iso-forms of $\mathrm{IP}_{3} \mathrm{~K}$ 's, it appears that while they generally have an effect on cell migration, the exact effect may be tissue and isoform dependent.

Unlike $\mathrm{IP}_{3}$, whose role as an intracellular mediator of calcium release is well established, significance of $\mathrm{IP}_{4}$ is far from clear. Original belief that $\mathrm{IP}_{3}$ kinase's only function to inactivate $\mathrm{IP}_{3}$, and thereby terminate calcium signaling is certainly incorrect. Several intriguing possibilities have been suggested for the functional significance of $\mathrm{IP}_{4}$ generated by the action of $\mathrm{IP}_{3} \mathrm{~K}$ on $\mathrm{I}(1,4,5) \mathrm{P}_{3}$. $\mathrm{IP}_{4}$ is capable of binding to proteins containing class 1 
pleckstrin homology domain [Cozier et al., 2000]. In some instances, such as Ras GAP activity of $\mathrm{GAP} 1{ }^{\mathrm{IP}} 4 \mathrm{BP}$ was inhibited by phospholipids, but activated by $\mathrm{IP}_{4}$ [Cullen et al., 1995]. In proteins with more than one pleckstrin homology domain, binding of $\mathrm{IP}_{4}$ to one of those sites, modulates the binding of the other PH site to its target [Stricker et al., 2006] including $\mathrm{PIP}_{3}$. New evidence [Miller et al., 2007] has implicated $\mathrm{IP}_{4}$ in negative modulation of store operated calcium channel.

When $\mathrm{IP}_{4}$ is considered as the "soluble version" of $\mathrm{PIP}_{3}$ and because of its capability to bind to PH domain, depending on the cell type and the specific protein being regulated (i.e., whether it has one or more $\mathrm{PH}$ domains), several possible interaction scenarios are possible. In our system, $m$-calpain bound to PIP $_{2}$ is localized in the rear of the cell and plays an important role in cell detachment and locomotion [Shao et al., 2006]. Epidermal Growth factor mediated activation of $m$-calpain is mediated through ERK-phosphorylation. In this context it is interesting to note that Burton et al., have demonstrated that $\mathrm{IP}_{3} \mathrm{~K}$ localization to the cytoskeletal and its further regulation of activity by calmodulin [Lloyd-Burton et al., 2007].

While data reported in this publication are consistent with other recent observations that $\mathrm{IP}_{3} \mathrm{~K}$ isoenzymes through ERK phosphorylation may modulate cell migration, additional experiments with overexpressed kinase dead mutants of various isoenzymes as well as simultaneous determination of $\mathrm{IP}_{4}$ levels will be required to prove a causal relationship.

\section{REFERENCES}

Berridge MJ. Inositol trisphosphate and calcium signaling. Nature. 1993; 361:315. [PubMed: 8381210]

Bird GS, Putney JW Jr. Effect of inositol 1,3,4,5-tetrakisphosphate on inositol trisphosphate-activated $\mathrm{Ca}^{2+}$ signaling in mouse lacrimal acinar cells. J. Biol. Chem. 1996; 271:6766. [PubMed: 8636098]

Chang Y, Choi G, Bae Y, Burdett M, Moon H, Lee JW, Gray NS, Schutz PG, Meijer L, Chung S, Choi KY, Suh P, Ryu SH. Purine-based inhibitors of inositol -1,4,5-trisphosphate-3-kinase. Chem. Bio. Chem. 2002; 9:897.

Chen P, Xie H, Sekar MC, Gupta KB, Wells A. Epidermal growth factor receptor-mediated cell motility: phospholipase $\mathrm{C}$ activity is required, but MAP kinase activity is not sufficient for induced cell movement. J. Cell Biol. 1994; 127:847. [PubMed: 7962064]

Chen P, Murphy-Ullrich J, Wells A. The role of gelsolin in actuating EGF receptor-mediated cell motility. J. Cell Biol. 1996; 134:689. [PubMed: 8707848]

Cozier GE, Lockyer PJ, Reynolds JS, Kupzig S, Bottomley JR, Millard TH, Banting G, Cullen PJ. $\mathrm{GAP}_{1 \mathrm{IP}} \mathrm{BP}$ contains a novel group 1 pleckstrin homology domain that directs constitutive plasma membrane association. J. Biol. Chem. 2000; 275:28261. [PubMed: 10869341]

Cullen PJ, Hsuan JJ, Truong O, Letcher AJ, Jackson TR, Dawson AP, Irvine RF. Identification of specific I(1,3,4,5)P4-binding protein as a member of GAP1 family. Nature. 1995; 376:527. [PubMed: 7637787]

Dewaste V, Roumans D, Moreau C, Erneux C. Cloning and expression of a full-length cDNA encoding human inositol 1,4,5-trisphosphate 3-kinase B. Biochem. Biophys. Res. Commun. 2002; 291:400. [PubMed: 11846419]

Eva R, Bouyoucef-Chercalli D, Patel K, Cullen PJ, Banting G. IP $_{3}$ 3-kinase opposes NGF driven neurite outgrowth. PLoS One. 2012; 7:e32386. [PubMed: 22384237]

Galding A, Chang P, Lauffenburger DA, Wells A. Epidermal growth factor receptor activation of calpain is required for fibroblast motility and occurs via an ERK/MAP kinase signaling pathway. J. Biol. Chem. 2000; 275:2390. [PubMed: 10644690] 
Galding A, Uberall F, Keyse SM, Lauffenburger DA, Wells A. Membrane proximal ERK signaling is required for $\mathrm{m}$-calpain activation downstream of EGF receptor signaling. J. Biol. Chem. 2001; 276:23341. [PubMed: 11319218]

Helfman DM, Levy ET, Berthier C, Shtutman M, Riveline D, Grosheva I, Lachish-Zalait A, Elbaum M, Bershadsky AD. Caldesmon inhibits nonmuscle cell contractility and interferes with the formation of focal adhesions. Mol. Biol. Cell. 1999; 10:3097. [PubMed: 10512853]

Irvine RF, Lloyd-Burton SM, Yu JC, Letcher AJ, Schell MJ. The regulation and function of inositol 1,4,5-trisphosphate 3-kinases. Adv. Enzyme Regul. 2006; 46:314. [PubMed: 16857241]

Lauffenburger DA, Horwitz AF. Cell migration: A physically integrated molecular process. Cell. 1996; 84:359. [PubMed: 8608589]

Lloyd-Burton SM, Yu JC, Irvine RF, Schell MJ. Regulation of inositol 1,4,5-trisphosphate 3-kinases by calcium and localization of cells. J. Biol. Chem. 2007; 282:9526. [PubMed: 17284449]

Marechal Y, Peseese X, Jie Y, Pouillon V, Perez-Morga D, Daniel J, Izui S, Cullen PJ, Leo O, Luo HR, Erneux C, Schurmans S. Inositol 1,3,4,5-tetrakisphosphate controls proapoptotic Bim gene expression and survival in B cells. Proc. Natl. Acad. Sci. 2007; 104:13978. [PubMed: 17709751]

Miller AT, Sanberg M, Huang YH, Young M, Sutton S, Sauer K, Cooke MP. Production of Ins(1, 3, 4, 5)P4 mediated by the kinase Itpkb inhibits store-operated calcium channels and regulates B cell selection and activation. Natl. Immunol. 2007; 8:514.

Miller AT, Chamberlain PP, Cooke MP. Beyond $\mathrm{IP}_{3}$ : Roles for higher order inositol phosphates in immune signaling. Cell Cycle. 2008; 7:463. [PubMed: 18235237]

Shao H, Chou J, Baty CJ, Burke NA, Watkins SC, Stolz DB, Wells A. Spatial localization of mcalpain to plasma membrane by phosphoinositide biphosphate binding during epidermal growth factor receptor-mediated activation. Mol. Cell Biol. 2006; 26:5481. [PubMed: 16809781]

Stricker R, Chow KM, Walther D, Hanck T, Hersh LB, Reiser G. Interaction of the brain specific protein $\mathrm{p} 42 \mathrm{IP}_{4} /$ Centaurin-alpha1 with the peptidase nardilysin is regulated by the cognate ligands p42IP 4 , PtdIns $(3,4,5) \mathrm{P} 3$ and Ins $(1,3,4,5) \mathrm{P} 4$, with stereospecificty. J. Neurochem. 2006; 98:343. [PubMed: 16805830]

Windhorst S, Blechner C, Lin H, Elling C, Nalaswoski M, Kirchberger T, Guse AH, Mayr GW. Ins(1, 4, 5)P3 3-kinase-A overexpression induces cytoskeletal reorganization via a kinase-independent mechanism. Biochem. J. 2008; 414:407. [PubMed: 18498254]

Windhorst S, Fliegert R, Blechner C, Möllmann K, Hosseini Z, Günther T, Eiben M, Chang L, Lin HY, Fanick W, Shumacher U, Brandt B. Inositol 1-4-5-trisphosphate 3-kinase-A is a new cell motility-promoting protein that increases the metastatic potential of tumor cells by two functional activities. J. Biol. Chem. 2010; 285:5541. [PubMed: 20022963] 


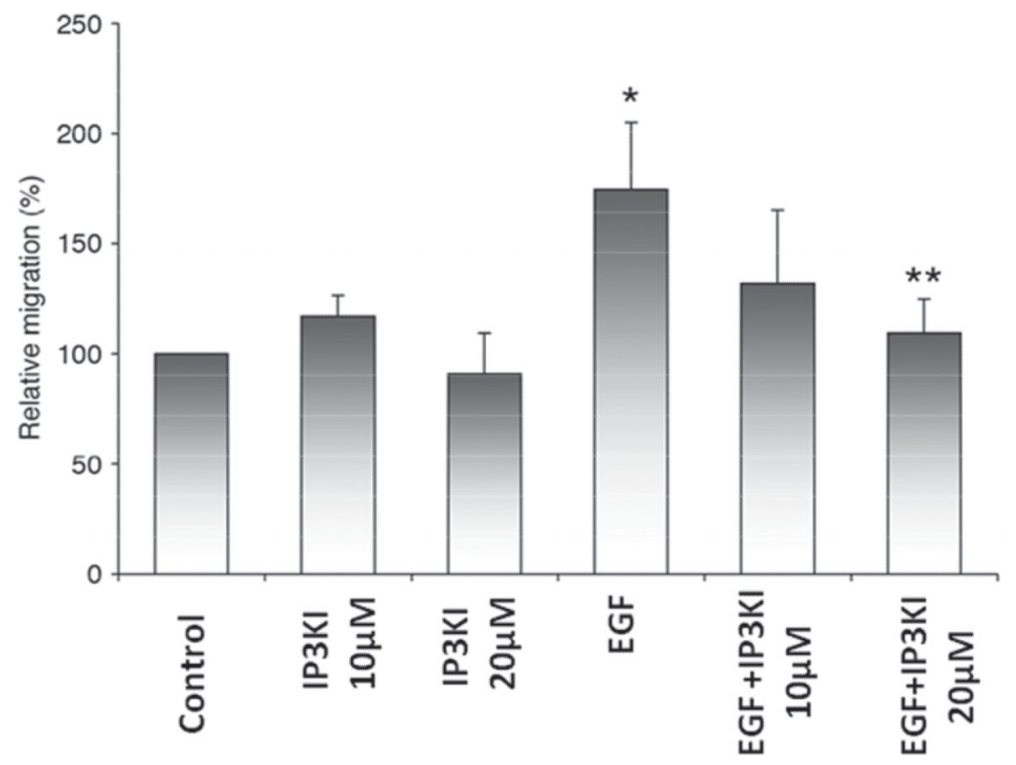

Figure 1.

Effect of $\mathrm{IP}_{3} \mathrm{KI}$ on EGF-stimulated cell migration in endothelial cell-Cells were treated with or without EGF, in presence and absence of $\mathrm{IP}_{3} \mathrm{KI}$ inhibitor overnight at $37^{\circ} \mathrm{C}$.

Migration was measured by the ability of cells to move into the acellular area. *:

Significantly different from the control $(p<0.05)$; **: Significantly different from EGFinduced $(p<0.05)$. 
A

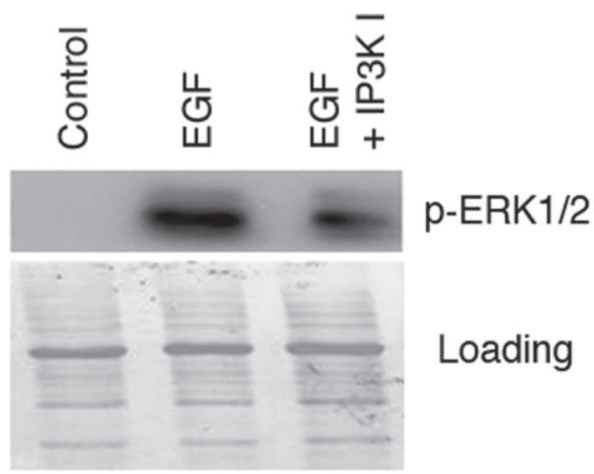

\section{B}

$\begin{array}{rcccccc}\text { EGF } & - & + & + & + & + & + \\ \mathrm{IP} 3 \mathrm{KI}(\mu \mathrm{M}) & 0 & 0 & 5 & 10 & 15 & 20\end{array}$

\section{$44 \mathrm{kDa}$} $42 \mathrm{kDa}$

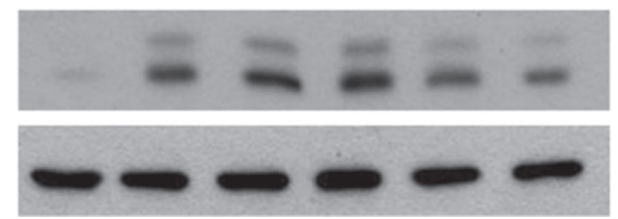

p-ERK $1 / 2$

$42 \mathrm{kDa}$

Figure 2.

Effect of $\mathrm{IP}_{3} \mathrm{KI}$ on EGF stimulated ERK phosphorylation: Quiescent endothelial cells incubated with $\mathrm{IP}_{3} \mathrm{KI}$ or DMSO (control) for $4 \mathrm{hrs}$, followed by $15 \mathrm{~min}$ stimulation with EGF. Solubilized protein separated on $10 \%$ SDS gel and WB probed with rabbit polyclonal against phosphorylated ERK1/2. (A) Endothelial cells stimulated with $10 \mathrm{nM}$ EGF with or without $20 \mu \mathrm{M} \mathrm{IP}{ }_{3} \mathrm{KI}$ pre-incubation; (B) pre-incubated with increasing concentrations of $\mathrm{IP}_{3} \mathrm{KI}$ for $4 \mathrm{hrs}$. Shown are representative of three independent experiments. 


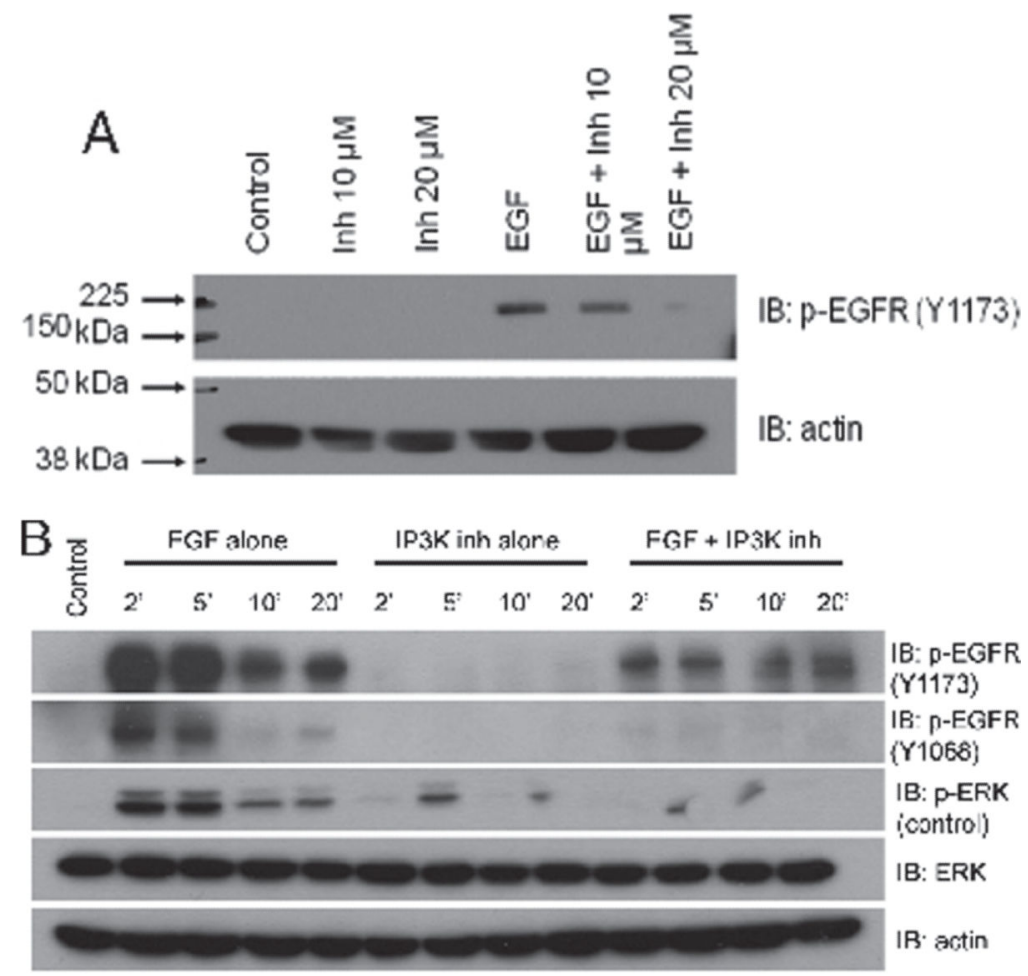

Figure 3.

Experiments were performed as described in Methods. Cells were pre-incubated for 4 hours in presence or absence of $\mathrm{IP}_{3} \mathrm{KI}$ followed by stimulation with EGF [10 nM] for (A) 10 minutes; and (B) varying period of time and western blot probed for $p$-EGFR (Y 1173), $p$ EGFR (Y 1068); $p$-ERK, ERK and actin. Shown are representative of at least three independent replicate gels. 


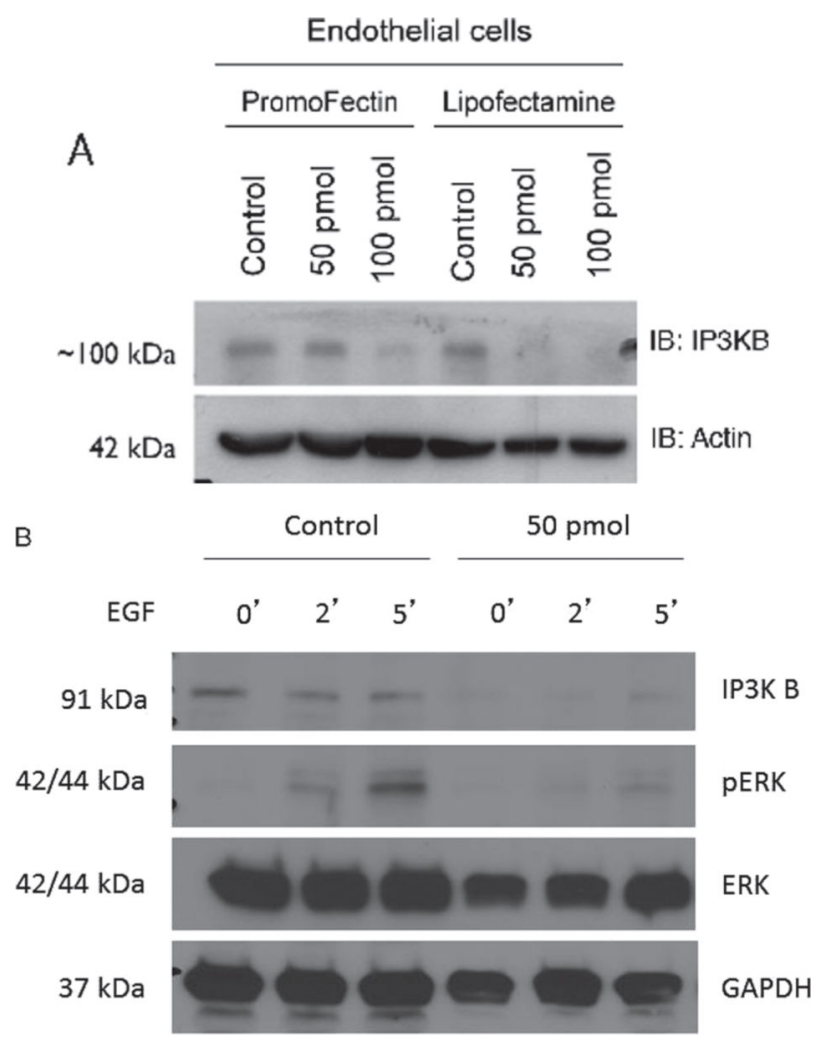

Figure 4.

(A) siRNA transfected into endothelial cells by two different transfection agents.

Downregulation of $\mathrm{IP}_{3} \mathrm{~KB}$ was measured by Western blot. As Lipofectamine produced more consistent down regulation of $\mathrm{IP}_{3} \mathrm{~KB}$, it was used for further investigation. (B) Cells were treated with either 0 or 50 pmol of siRNA for $\mathrm{IP}_{3} \mathrm{~KB}$ downregulation as described in the Methods and treated with or without EGF (10 nM) for 2 or 5 minutes. 